\title{
Estimation of Stock Reproductive Potential: History and Challenges for Canadian Atlantic Gadoid Stock Assessments
}

\author{
Edward A. Trippel \\ Fisheries and Oceans Canada, Biological Station \\ St. Andrews, New Brunswick, Canada E5B 2L1
}

\begin{abstract}
The knowledge and scientific history of maternal and paternal aspects of reproduction dates back several decades, though only recently are fishery scientists and managers giving this subject area greater attention in the provision of management advice. This paper outlines and summarizes several recent advances made in understanding the importance of variation in gadoid reproductive output as a function of spawner age, size, maturation, condition and reproductive history. An assembled score-card applied to 45 Canadian Atlantic gadoid stock assessments conducted from 1985 to 1998 portrays the evolution and current degree to which this scientific knowledge has been incorporated into fishery advice in eastern Canada. For future research, recommendations are made which promote the integration of basic reproductive biology into groundfish stock assessments. These emerging policies encourage managers worldwide to initiate relevant sampling programs which will lead to improved stock conservation reference points. A new term referred to as stock reproductive potential (SRP) is introduced. Compared to spawning stock biomass and population fecundity, SRP more accurately represents the annual variation in a stock's ability to produce viable eggs and larvae that may eventually recruit to the adult population or fishery. SRP is a term (concept) which will likely evolve in such a manner as to provide a more accurate measure of a stock's reproductive potential.
\end{abstract}

Key words: cod, egg quality, fecundity, management, recruitment, stock assessment, spawning stock biomass (SSB), stock reproductive potential (SRP)

\section{Introduction}

In eastern Canada, commercial fishing moratoria still remain in effect for the majority of groundfish stocks as efforts to rebuild these resources continue. From July 1992 to January 1994, fishing moratoria were imposed on six principal Atlantic cod (Gadus morhua) stocks and one haddock (Melanogrammus aeglefinus) stock. The effects of these closures on eastern Canadian cod landings have been significant, as the amount harvested in 1997 was 37000 metric tons compared to 425000 metric tons in 1990. In addition to the declines in adult abundance which led to these closures, fundamental changes have occurred in the structure of spawning stock biomass (SSB) for these northwest Atlantic gadoid stocks. These changes include the loss of large, old, experienced spawners, younger ages and smaller sizes at sexual maturity, reduced egg quality, shorter spawning period, as well as low condition factor of individuals
(Hutchings and Myers, 1993; Trippel, 1995; Trippel et al., 1997a,b; Trippel, 1998; Lilly, MS 1997; Lambert and Dutil, 1997a). These altered adult characteristics are considered to be symptoms of populations under stress. In April, 1998, the Committee on Status of Endangered Wildlife in Canada (COSEWIC) listed Atlantic cod as "Vulnerable" on their annual list of species at risk. "Vulnerable" is defined as "a species of special concern because of characteristics that make it particularly sensitive to human activities or natural events."

In 1993, the Fisheries Resource Conservation Council (FRCC) of Canada was formed as an outcome of the fishing crisis that developed in the Canadian Atlantic. The FRCC is made up of individuals from university, government, and industry. The role of the FRCC is to: (1) consider information about the status of fish stocks, (2) consult broadly with interested stakeholders and (3) 
make recommendations about conservation requirements for groundfish stocks. Conservation has been a key issue with the Council. Through their consultations they noted in their report of July 1997 (FRCC, MS 1997) that:

"One factor in the collapse of Atlantic Canada's groundfish fisheries was a lack of attention to the logical connection between spawning and future recruitment of young fish".

Furthermore,

"while it is obvious that a decrease in the number of spawners to very low levels must have a negative impact on the future production of new young fish, such a connection was not usually incorporated into stock assessments nor into fishery management decision making. This was largely because of the difficulty faced by scientists in proving that such links exist, even though they logically must. In the future, such links should be assumed."

They also adopted a Precautionary Approach (FAO, MS 1995) in their provision of advice. For example,

"It is reasonable to assume that depleting the spawning potential (catching too many spawners, particularly older fish) will tend to damage future recruitment, and indeed, that for each stock, there is a certain critical spawning potential below which the chance of stock collapse becomes substantial. We will never know these levels precisely, so a Precautionary Approach suggests that while science and management must understand as much as possible about the spawning process, in any case spawning stocks must be kept well above likely critical levels".

Given the proposed establishment of these critical levels, they were clear that:

"the reproductive capacity of the stock appears not to be properly measured by the absolute volume of spawning biomass, as generally assumed."

\section{Spawning Stock Biomass Not Equal to Stock Reproductive Potential}

There is substantial support for these FRCC statements. The assumption that SSB adequately represents stock reproductive potential has been prevalent for some time in the fisheries literature (Myers et al., 1994), as commonly used biological reference points rely heavily on the term SSB (Table 1). As well, standard practices and assumptions often made when using stock-recruitment models developed by Beverton and Holt (1957), Ricker (1954) and Shepherd (1982) have incorporated the term SSB (although these models were originally developed using fecundity; Rothschild and Fogarty, 1989; Koslow, 1992). In many instances, a given weight of adult biomass is presumed to have an equal likelihood of generating the same level of recruitment. This deduction occurs regardless of whether the SSB is comprised of scrawny, low condition fish, a large fraction of which may be skipping reproduction, or a well fed population of highly fecund fish. This disparity in reproductive potential among equal values of SSB is why the traditional use of this term is so potentially problematic.

In light of these issues, the intent of this paper is to (1) review research activity on cod reproduction, (2) introduce the term stock reproductive potential (SRP) as an alternative to spawning stock biomass (SSB), and (3) review Canadian gadoid stock assessments in their integration of reproductive biology in stock-specific management advice between 1985-1997/98.

Research to address the implications of changes in adult age/size structure and other issues concerning cod reproductive potential accelerated in the late-1980s and 1990s and took advantage of the ability of cod to spawn freely in captivity. These research efforts have run parallel and gained in relevance and momentum with mounting stock collapses and failure of their recoveries to date (Myers et al., 1997). Experiments on reproductive biology of captive marine batch-spawning fish, most notably on cod, were conducted in several marine laboratories having responsibilities and/or scientific interest in the fishery resources of the north Atlantic and Baltic Sea (Table 2). At the St. Andrews Biological Station, considerable effort has been made to evaluate spawning potential of cod of both sexes (Table 3 ). Research on captive cod egg production has also recently been conducted in Canada at the Maurice Lamontagne Institute in Mont Joli, Québec (Lambert and Dutil, 1999), the Northwest Atlantic Fisheries Centre, St. John's, Newfoundland (Wilson-Short et al., 1995), and Memorial University of Newfoundland (Burton et al., 1997). This Canadian effort, pioneering work 
TABLE 1. Several key papers outlining biological reference points used in fisheries management. Many of these reference points utilize the term spawning stock biomass (SSB). This list is not meant to be all encompassing.

\section{Maguire and Mace (1993)}

Biological reference points for Canadian Atlantic gadoid stocks

- Yield per recruit $\left(F_{M S Y}, F_{0.1}, F_{\text {max }}\right)$

- Spawning stock biomass per recruit (SPR)

- Stock-recruitment relationships (e.g. Serebryakov 1991)

\section{Goodyear (1993)}

Spawning stock biomass per recruit in fisheries management: foundation and current use

- \% SPR is recommended as a reference point for defining overfishing since it is based on the premise of stock replacement.

- common basis of overfishing definition for US marine fisheries

- $F_{\text {med }}, F_{\text {rep }}$ (Sissenwine and Shepherd 1987)

\section{Mace and Sissenwine (1993)}

How much spawning per recruit is enough?

\section{Caddy and Mahon (1995)}

FAO report on reference points for fisheries management.

\section{ICES (MS 1997)}

Report of the Study Group on the Precautionary Approach to Fisheries Management

- $F_{\text {crash }}$

\section{Serchuk et al. (MS 1997)}

Report of Working Group of the NAFO Scientific Council on the Precautionary Approach

- Biomass reference points $\left(B_{\text {lim }}, B_{\text {buf }}, B_{\text {target }}\right)$

- Fishing mortality reference points $\left(F_{\text {lim }}, F_{\text {buf }}, F_{\text {target }}\right)$

- Precautionary reference points (lim, buf, and target)

by Norwegian scientists (Solemdal, MS 1970; Kjesbu, 1989; Kjesbu et al., 1996; Solemdal et al., MS 1992; MS 1995) and recent studies in Sweden (Nissling et al., 1998), Iceland (Marteinsdottir and Thorarinsson, 1998; Marteinsdottir and Steinarsson, 1998) and Norway (Solemdal, 1997; Marshall et al., 1998; Kjesbu et al., 1998) have impacted analyses of stock-recruitment data. Many scientists no longer view a spawning population as a single mass of animals that collectively return each year to a spawning ground to mate, shed gametes, and redisperse. The term SSB, or the collective weight of mature fish, reflects this conventional approach. Instead, these scientists and others are beginning to partition an adult population into its component parts and to discuss, hypothesize and test how each may be partly responsible for future recruitment (Ellertsen and Solemdal, MS 1990; Marshall et al., 1998; MacKenzie et al., MS 1998). Ulltang (1996) indicates that at present only a fraction of the potential information on spawning potential is included in groundfish stock assessments (Fig. 1).

As an alternative to SSB, a new term is introduced in this paper. This term is referred to as Stock Reproductive Potential or SRP. Compared to SSB, SRP more accurately represents the annual variation in a stock's ability to produce viable eggs and larvae that may eventually recruit to the adult population or fishery. Although the SRP acronym has not been previously used, this parental aspect of stock-recruitment relationships has been advanced in work by Marshall et al. (1998) and Murawski et al. (1999).

SSB for a given year is determined by the number of mature fish in each cohort multiplied by their respective mean weights. The determination of SRP is more complicated and extends beyond estimation of population fecundity (Table 4). A 
TABLE 2. Research institutions in the North Atlantic and Baltic Sea area involved in the conduct of experiments on the reproductive biology of captive cod.

\begin{tabular}{|c|c|}
\hline Institution & Year(s) of research activity, contributors and source of cod \\
\hline $\begin{array}{l}\text { Institute of Marine Research, } \\
\text { Bergen, Norway }\end{array}$ & $\begin{array}{l}\text { 1968-72 - Solemdal } \\
\text { 1986-present - Kjesbu and others } \\
\text { Coastal cod 1989-93 (long term) } \\
\text { Arcto-Norwegian cod 1991-present }\end{array}$ \\
\hline $\begin{array}{l}\text { Ar Laboratory, Gotland, Sweden } \\
\text { Institute of Marine Research, } \\
\text { Lysekil, Sweden }\end{array}$ & $\begin{array}{l}\text { 1995-present - Nissling, Larsson, Vallin, Frohlund } \\
\text { Baltic cod }\end{array}$ \\
\hline $\begin{array}{l}\text { Marine Research Institute, } \\
\text { Reykjavik, Iceland }\end{array}$ & $\begin{array}{l}\text { 1994-present - Marteinsdottir, Steinarsson } \\
\text { Icelandic cod }\end{array}$ \\
\hline $\begin{array}{l}\text { Maurice Lamontagne Institute, } \\
\text { Mont-Joli, Québec, Canada }\end{array}$ & $\begin{array}{l}\text { 1995-present - Lambert, Ouellet, Dutil, Browman } \\
\text { NAFO } 4 \text { T }\end{array}$ \\
\hline $\begin{array}{l}\text { St. Andrews Biological Station, } \\
\text { St. Andrews, New Brunswick, } \\
\text { Canada }\end{array}$ & $\begin{array}{l}\text { 1983-84 - Waiwood, Chambers } \\
\text { 1991-present - Trippel, Rakitin, Fordham, Ferguson, Neilson } \\
\text { NAFO } 4 \text { X }\end{array}$ \\
\hline $\begin{array}{l}\text { Northwest Atlantic Fisheries Centre, } \\
\text { St. John's, Newfoundland, Canada }\end{array}$ & $\begin{array}{l}1994 \text { - Morgan, Crim, Wilson-Short } \\
\text { NAFO 2J3KL, "trawling effects" }\end{array}$ \\
\hline $\begin{array}{l}\text { Memorial University, St. John's, } \\
\text { Newfoundland, Canada }\end{array}$ & $\begin{array}{l}1993 \text { - Burton, Penney, Biddiscombe } \\
\text { NAFO 3L, "non-annual maturation" }\end{array}$ \\
\hline $\begin{array}{l}\text { Dalhousie University, } \\
\text { Halifax, Nova Scotia, Canada }\end{array}$ & $\begin{array}{l}\text { 1995-96 - Hutchings, Bishop, McGregor-Shaw } \\
\text { NAFO 4W, "mating behaviour" }\end{array}$ \\
\hline
\end{tabular}

portion of the term SRP accounts for differences in egg viability between first and second-time spawning cod, as applied to Georges Bank cod (Murawski et al., 1999). Improved estimation of stock reproductive potential led to an improvement over the use of SSB in the fitting of an equation for the reproductive potential-recruitment relationship for northeast Arctic cod (Marshall et al., 1998). SRP is a term which will likely evolve to provide the most accurate measure of a stock's reproductive potential.

\section{Management Measures for Other Fishes (Non- Gadoids)}

In North America in the 1980s, substantial debate occurred over slot size limits, protection of old fish, and minimum and maximum body lengths for species such as walleye (Stizostedion vitreum), bass (Mircropterus spp.) and trout (Salvelinus spp.) (Jensen, 1981; Brousseau and Armstrong, 1987; Scarnecchia et al., 1989; Novinger, 1990; Trippel, 1993). Consequently, freshwater fisheries manage- ment embraced an intra-population concept to protect spawners in advance of marine fisheries management.

At present, a number of policies exist in Canadian provinces and states in the USA where live release of large adults is mandatory. This is in contrast to previous freshwater management practices which were based on creel limits alone (i.e. maximum possession limit of a species regardless of body size, although return of juvenile sizes were sometimes enforced). Moreover, it is interesting that fisheries management of a largebodied marine anadromous species has viewed reproductive biology at the individual level to be a more important part of their restoration programs than management practices pertaining to long-lived demersal marine species.

An individual Atlantic salmon (Salmo salar) has the potential to spawn more than 2 or 3 times during its life span. Since 1984, retention of these large multi-sea-winter fish has been prohibited in 
TABLE 3. Research conducted on Atlantic cod at the St. Andrews Biological Station pertaining to the evaluation of stock reproductive potential.

\begin{tabular}{|c|c|c|}
\hline Captive/wild & & Reference \\
\hline \multicolumn{3}{|c|}{ Sperm quality } \\
\hline Captive & $\begin{array}{l}\text { Virgin and repeat spawners, motility, spermatocrit, } \\
\text { fertilization, hatching success }\end{array}$ & Trippel and Neilson (1992) \\
\hline Wild & $\begin{array}{l}\text { Gonadosomatic index, spermatocrit, fertilization, hatching, } \\
\text { timing of spawning, male age, size }\end{array}$ & Trippel and Morgan (1994a, b) \\
\hline Captive & $\begin{array}{l}\text { Condition factor, sire size, mate competition, sperm competi- } \\
\text { tion, DNA fingerprinting, seasonal and annual changes in } \\
\text { sperm density }\end{array}$ & Rakitin et al. (1999a, b) \\
\hline Captive & Sperm motility patterns - maternal effects, salinity & Litvak and Trippel (1998) \\
\hline \multicolumn{3}{|c|}{ Egg Quality } \\
\hline Captive & Egg size, maternal length, condition factor, seasonal changes & Chambers and Waiwood (1996) \\
\hline Captive & $\begin{array}{l}\text { First and second time spawners, egg size, fertilization rate, } \\
\text { hatching rate, spawning duration, larval dry weight, relative } \\
\text { yolk sac size, seasonal changes }\end{array}$ & Trippel (1998) \\
\hline \multicolumn{3}{|c|}{ Maturity and Spawning } \\
\hline Wild & $\begin{array}{l}\text { Changes in age and length at sexual maturity. Test of methodol- } \\
\text { ogy to assess maturity stages (visual/histological) }\end{array}$ & Trippel et al. (1997a) \\
\hline Wild & Mating - leks - spawning aggregation - sex segregation & Morgan and Trippel (1996) \\
\hline Wild & Multiple spawning grounds within a management unit & Benham and Trippel (MS 1998) \\
\hline Captive & Feeding behaviour in relation to spawning & Fordham and Trippel (1999) \\
\hline Wild & $\begin{array}{l}\text { Consequences of fishing pressure and early maturity on } \\
\text { lifetime fecundity. Mature fish are larger at age than immature } \\
\text { fish }\end{array}$ & Trippel et al. (1995) \\
\hline Wild & Females attain older ages and larger sizes than males & Hunt (1996) \\
\hline
\end{tabular}

parts of maritime Canada. To view the scientific interest in studying salmonid reproduction one need only examine the topic of several departmental research documents published by Dept. of Fisheries and Oceans, Canada scientists over the past 10-15 years (e.g. O'Connel and Reddin, MS 1983; Amiro et al., MS 1985; O'Connel, MS 1986; Ritter et al., MS 1990; O'Connel and Dempson, MS 1991). Salmon egg number, spawning areas, etc. are central to river management discussions and are manifested in a target egg production of $2.4 \mathrm{eggs} / \mathrm{m}^{2}$ of spawning ground. However, salmon biologists have large assumptions remaining in their models (e.g. universal application of the target egg deposition rate among all rivers).

In another large marine resource, the American lobster (Homarus americanus), recognition of spawning potential has been evident for over a century, as protection of "berried" or fecund females and of small lobsters $(<0.5 \mathrm{~kg})$ has been in effect in Canada since 1871. In Maine, a maximum size regulation has been in effect on lobsters since 1933 . Thus, managers of non-gadoid resources were first to recognize the importance of body size and preserving a balanced age structure - the benefits of which could include greater offspring quality and recruitment success.

\section{History of Maternal Factors and Application to Groundfish Stock Assessments}

Several review papers have recently been published which highlight the considerable amount of scientific activity directed at the subject of parent-progeny relationships in teleost fishes (Chambers and Leggett, 1996; Trippel et al., 1997b; Solemdal, 1997). Scientists have known for some time that the size and quality of an egg or larva is influenced by maternal physiological status. Female 


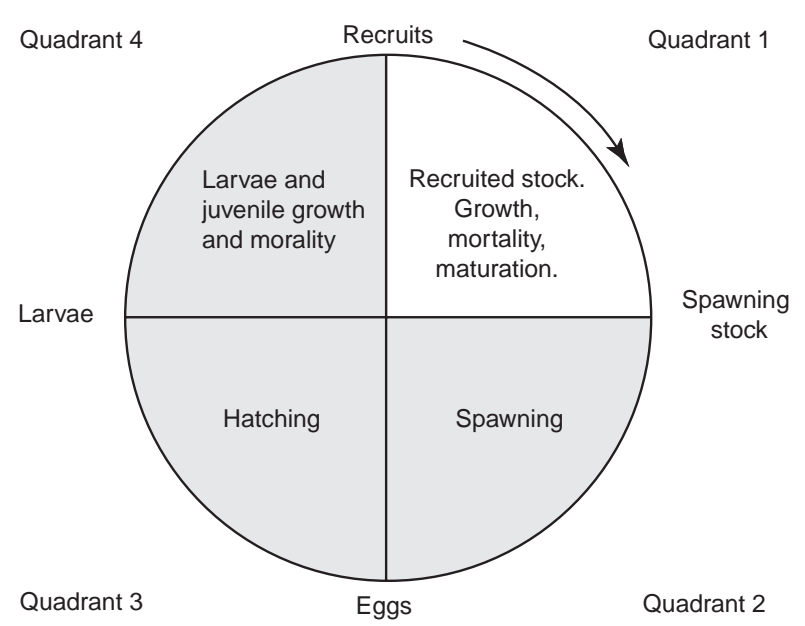

Fig. 1. Paulik (1973) figure which illustrates that stock assessment advice is commonly restricted to the unshaded area (growth, mortality and maturation - quadrant 1) and traditionally does not include subsequent life history stages involved in recruitment (quadrants 2-4). Sources: Ulltang (1996) and Solemdal (1997).

state, whether it be body size, years of reproductive experience, or ration during gametogenesis, can in some way alter egg quality and presumably influence larval quality and survivorship. In marine fish species, egg size has been shown to increase with fish body size in a number of studies (Table 5). These early reports of a maternal size-egg size relationship for several fish species were preceded by observations on cod (see Chambers and Waiwood, 1996). For example, smaller or younger females captured at Cape Ann, Massachusetts had smaller eggs than larger, older cod (Earll, 1880). Eggs of Atlantic cod in the Deutschen Bucht decreased in size throughout the spawning season (Heincke and Ehrenbaum, 1900). Older females arrived on the Lofoten spawning grounds earlier than younger ones (Sund et al., 1938). And more recently, in the 1990s, studies have been undertaken to examine various factors influencing cod egg viability (Table 6).

At first glance, if these studies have been so well documented, why then has there been such a time lag in their recognition and application to coldwater marine fisheries management? To appreciate the difficulty for fishery scientists to modify their standard practices one may wish to consider that historical levels of recruitment of northwest Atlantic groundfish have been extremely variable (Maguire and Mace, 1993). Traditionally, the size of SSB was not considered to have a significant impact on recruitment levels of batchspawning fish (e.g. Hutchings and Myers, 1994; Walters and Maguire, 1996). Only recently, with declines in stock sizes and recruitment levels, have cod reproductive studies gained recognition.

Prior to 1990, none of the Canadian Atlantic cod stock assessments that the author reviewed made mention of age and size at sexual maturity or any of the other reproductive parameters listed in Table 7. These assessments ranked low on a scale which measures the integration of reproductive parameters to evaluate stock reproductive potential. Using the score card shown in Table 7, each of the 45 Canadian Atlantic gadoid stock assessments reviewed received a score ranging from zero to a possible 10 (Table 8; Fig. 2; Appendices 1 and 2; the Appendices provide information on stock biomass, landings, and statements on fish reproduction made by stock assessment authors). From these scores, it is clear that the 1985 and 1990 annual Canadian stock assessments which were conducted prior to stock collapses did not identify critical SSB levels below which stocks should not be allowed to decline. Although not reported in the annual stock assessments, during 1985-90, there was some activity in analyzing stock-recruitment relationships for these stocks and in the development of maturity ogives (e.g. Beacham, 1983; Baird et. al., MS 1986; Rice and Evans, MS 1986). Perhaps these relationships and data were not reported because they were not perceived to lend themselves to reliable management advice, especially since the focus was on advice pertaining to yield-per-recruit analyses $\left(F_{0.1}\right)$.

Since the groundfish moratoria and a succession of several poor year-classes (e.g. Fig. 3 and 4) the importance of incorporating reproductive biology in Canadian stock assessment reports has been recognized. Scores of between 3-4 out of 10 have been recorded in the use of reproductive data and good examples of improvement have been noted, for example, in assessments of Div. 4VsW and Div. $2 \mathrm{~J}$ and $3 \mathrm{KL}$ cod and Div. 4TVW haddock. However, many other stock assessments continue to show only limited advancement in this aspect of stock status evaluation. 
TABLE 4. Various maternal and paternal reproductive attributes to be considered for estimation of stock reproductive potential (SRP). Parental attributes such as reproductive experience and condition factor, as well as environmental factors (e.g. water temperature), will interact to influence viable reproductive output per individual fish in a given year. Parental effects on larval viability are also shown. Predictive equations among the variables presented may be used to produce estimates that, in comparison with SSB estimates, more accurately reflect the annual variation in a fish stock's ability to produce viable eggs and larvae which may eventually recruit to the adult propulation. For examples see Marshall et al. (1998) for ArctoNorwegian cod and Murawski et al. (1999) for Georges Bank cod.

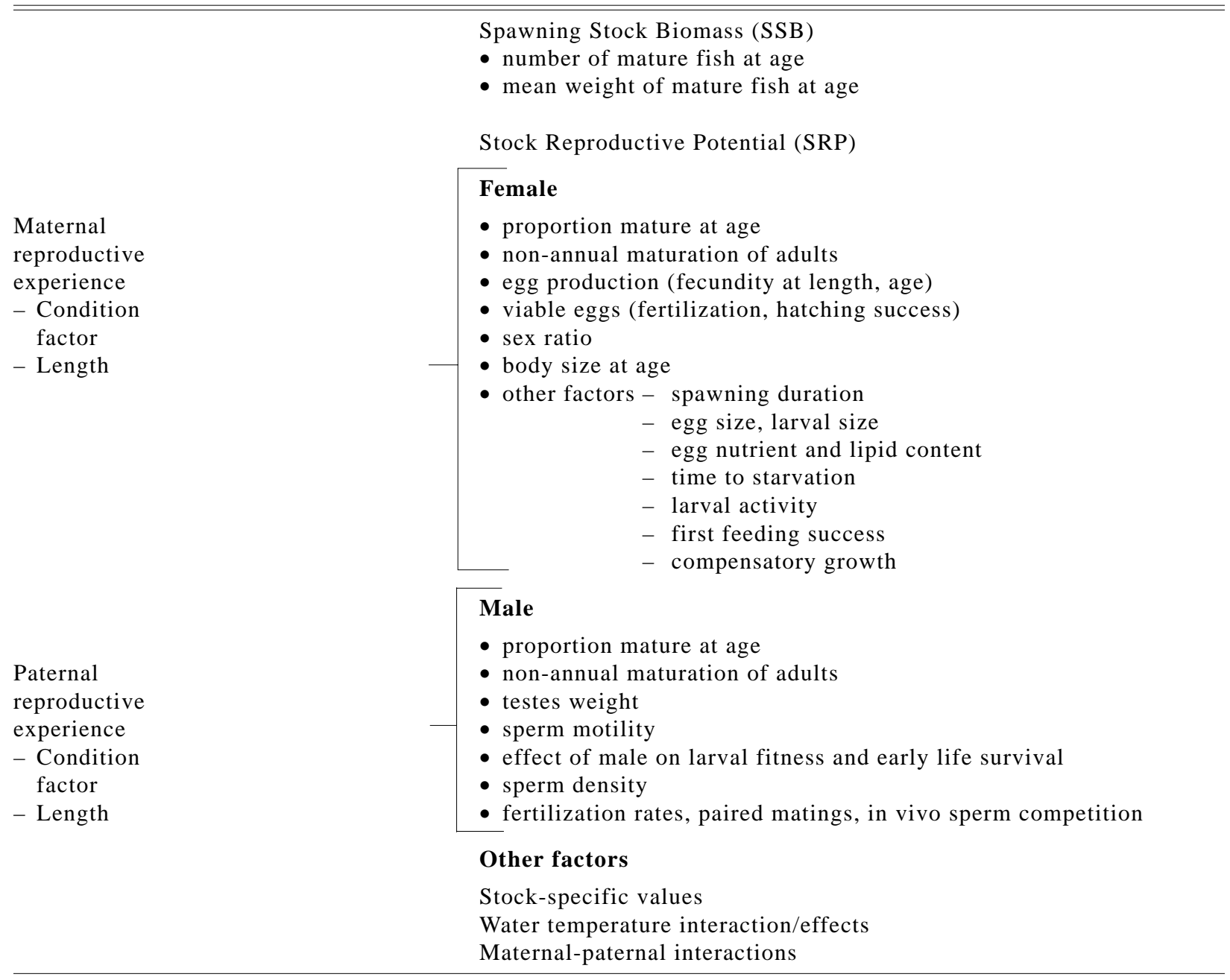

A surprising result was the score of $6 / 10$ noted for the 1985 Div. 4VW haddock assessment (Mahon et al., MS 1985). These authors assembled all possible reproductive data available at the time and provided evidence of three levels of recruitment at different stock sizes. This effort by Mahon et al., (MS 1985) revealed that, at least for this stock, the capacity to evaluate reproductive parameters in routine groundfish stock assessments was present in the mid-1980s.

\section{Future Research and Requirements to Estimate Stock Reproductive Potential (SRP)}

A review of stock assessment advice in eastern Canada reveals that some headway has been made towards incorporating reproductive biology into management advice, though this has been marginal. Effects of maternal factors on egg size, egg viability, spawning potential, and biological reference points have been explored in recent 
TABLE 5. First account of the positive effect of increased body size on egg size for several marine fish species.

\begin{tabular}{ll}
\hline \hline \multicolumn{1}{c}{ Species } & \multicolumn{1}{c}{ Source } \\
\hline Cod-Baltic & \multicolumn{1}{c}{ Grauman (MS 1964) } \\
$\quad$ - Norwegian coastal & Kjesbu (1989) \\
Herring (Clupea harengus) & Hempel and Blaxter (1967) \\
Argentine anchovy (Engraulis achoita) & de Ciechomski (1966) \\
Striped bass (Morone saxatilis) & Rogers and Westin (1981) \\
Haddock & Hislop (1988) \\
Winter flounder (Pseudopleuronectes americanus) & Buckley et al. (1991) \\
Queenfish (Seriphus politus) & DeMartini (1991) \\
Turbot (Scopthalmus maximus) & McEvoy and McEvoy (1991) \\
\hline
\end{tabular}

TABLE 6. Studies conducted on factors affecting egg viability of north Atlantic and Baltic Sea cod.

\begin{tabular}{ll}
\hline \hline \multicolumn{1}{c}{ Location } & \multicolumn{1}{c}{ Source } \\
\hline Norwegian coast & Solemdal et al. (MS 1992, MS 1995) \\
Bay of Fundy & Trippel (1998) \\
Iceland & Marteinsdottir and Steinarsson (1998) \\
Baltic Sea & Nissling and Westin (1991); Nissling et al. (1998) \\
\hline
\end{tabular}

TABLE 7. Score card used to rank fish stock assessments in their integration of data on fish reproductive biology. Stock assessment documents were reviewed for inclusion of the following 10 points. In scoring, each point was given equal weight though each affects the measurement of a stock's reproductive potential (SRP) differently.

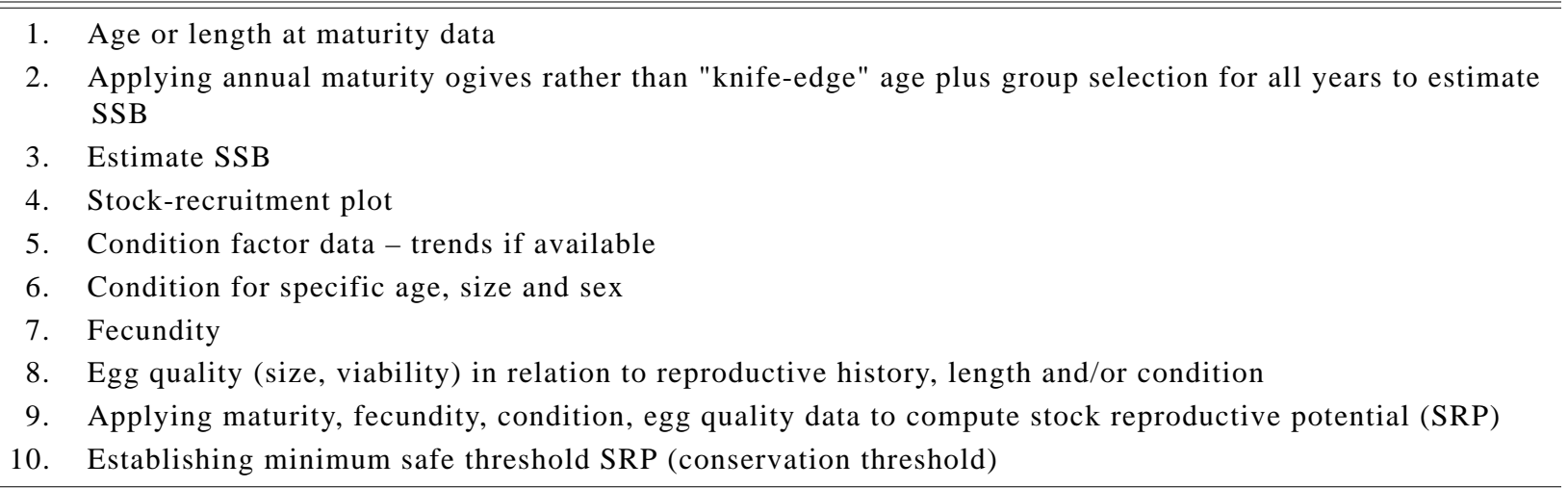

modeling initiatives (Trippel et al., 1997b; Marshall et al., 1998; Murawski et al., 1999), and further efforts of this kind are encouraged. Notwithstanding these efforts, the lack of attention given to reproductive biology in stock assessments may simply be a result of inadequate data. Perhaps scientific peer review led to the pronouncement that other problems in the assessment were more critical and required immediate attention. Regardless of the reason(s), if improvements are to be made, 


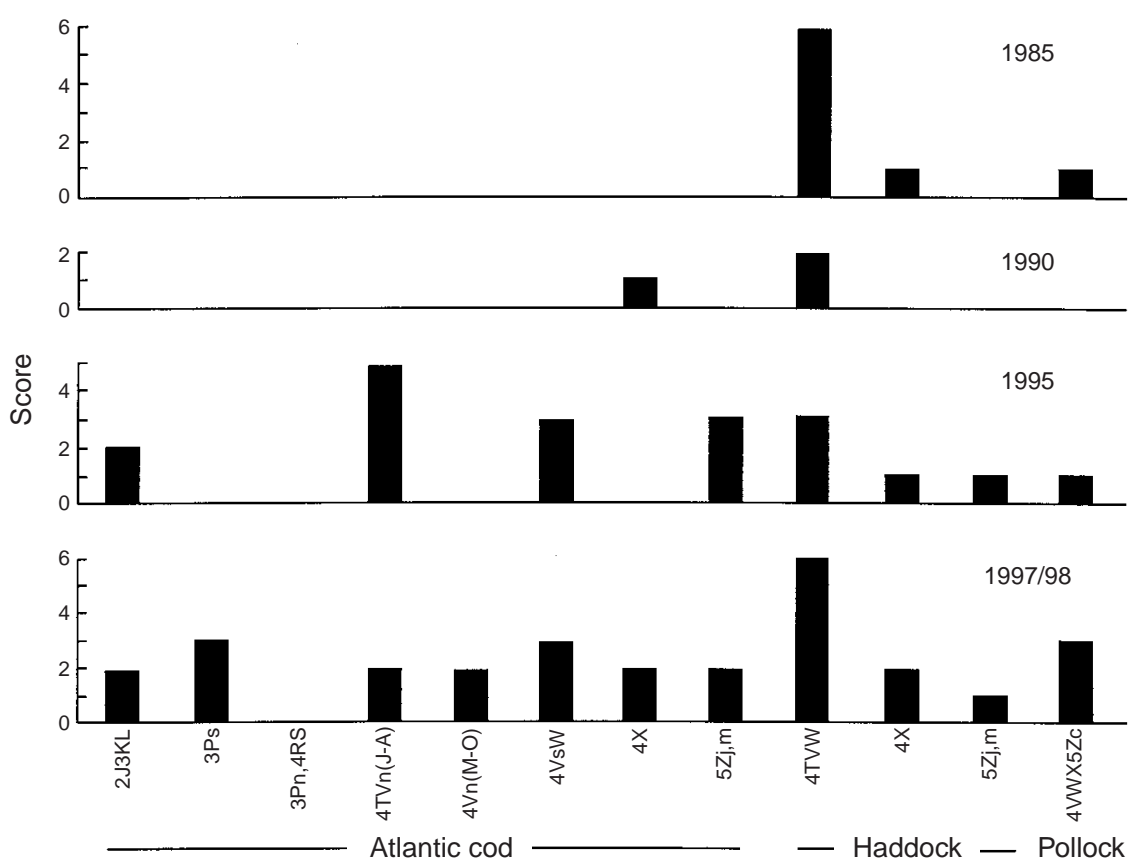

Fig. 2. Individual scores (out of 10) received by Canadian northwest Atlantic gadoid stock assessments in their use of data on fish reproductive biology (1985-1997/98). For method of scoring refer to Table 7 and for further details see Appendices 1 and 2.

TABLE 8. Average scores (out of 10) in the application of reproductive biology towards the estimation of a stock's reproductive potential in the Canadian Northwest Atlantic.

\begin{tabular}{lccc}
\hline \hline $\begin{array}{c}\text { Year of Stock } \\
\text { Assessment }\end{array}$ & $\begin{array}{c}\text { Cod } \\
\mathrm{n}=8 \text { stocks }\end{array}$ & $\begin{array}{c}\text { Haddock } \\
\mathrm{n}=3 \text { stocks }\end{array}$ & $\begin{array}{c}\text { Pollock } \\
\mathrm{n}=1 \text { stock }\end{array}$ \\
\hline 1985 & 0 & $\begin{array}{c}2.7 \\
\text { (range } 1-6)\end{array}$ & 1 \\
1990 & 0 & 0.7 & 0 \\
1995 & 1.6 & $\begin{array}{c}(0-2) \\
1.5\end{array}$ & 1 \\
$1997 / 98$ & $(0-5)$ & $\begin{array}{c}(1-3) \\
4\end{array}$ & 3 \\
& 2.1 & $(1-6)$ & \\
\hline
\end{tabular}

biologists will inevitably require the necessary support (funds, technical support, vessel time, etc.) to collect and analyze reproductive data.

The information that exists on the reproductive state of northwest Atlantic cod is poor. Unbelievably, fecundity has been recorded for $\sim 600$ individuals over the past century for all northwest Atlantic cod stocks combined (Table 9). Other than the outdated material for Gulf of Maine cod (Earll, 1880), no published fecundity data exist for the four southern cod stocks spanning from Cape Breton, Nova Scotia to Georges Bank. Collection of maturity data recently has been discontinued for several gadoid stocks (Trippel et al., 1997a). Lack of a maturity time series means that single year point estimates have to be applied to multiple years. Without proper maturity data one cannot discern 


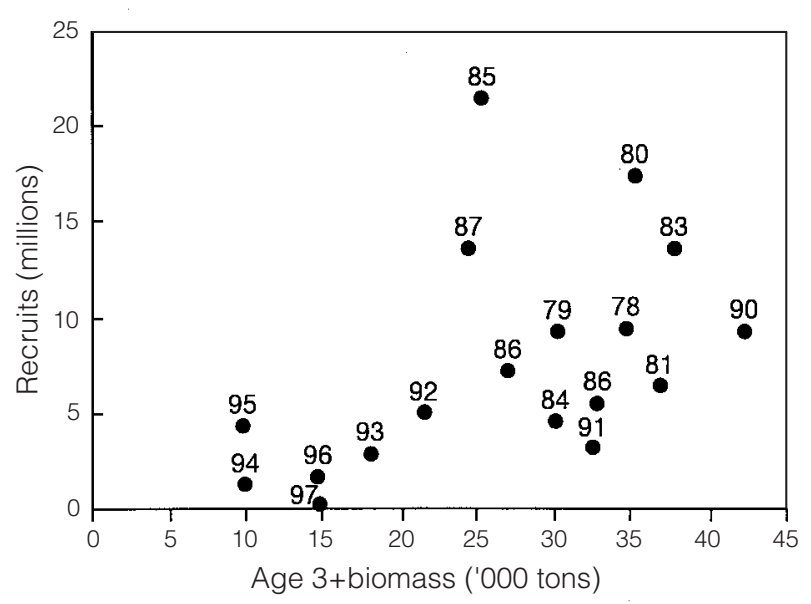

Fig. 3. Stock-recruitment relationship for Georges Bank cod (NAFO Subdivision $5 \mathrm{Zj}, \mathrm{m}$ ) using age $3+$ to represent adult biomass. Year-classes are marked. Source: DFO (MS 1998d).

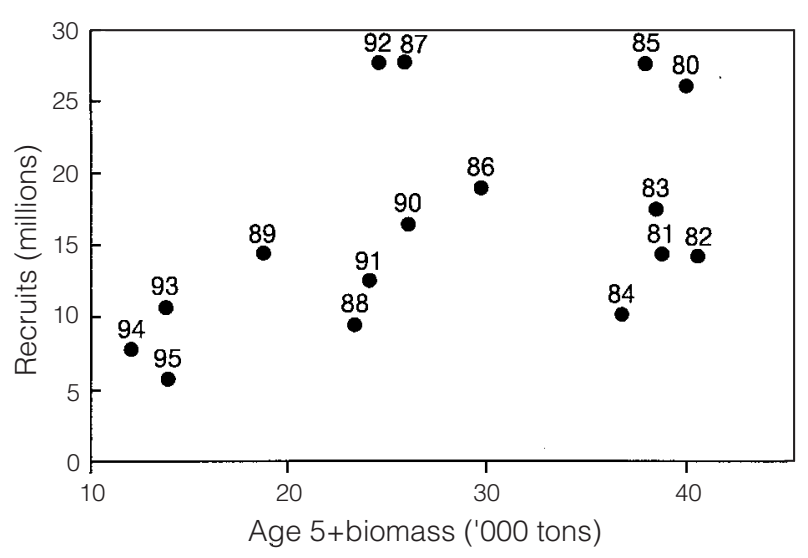

Fig. 4. Stock-recruitment relationship for Southern Scotian Shelf and Bay of Fundy cod (NAFO 4X) using age $5+$ to represent adult biomass. When age $3+$ was used to represent adult biomass the relationship was less clear. Year-classes are marked. Source: DFO (MS 1997c).

between first and second-time spawners of a population. This shortcoming is significant as virgin females have appreciably lower egg viability than repeat spawners (Solemdal et al., MS 1995; Trippel, 1998).

Sampling of wild fishes should be strongly encouraged to complement the captive fish studies which have dominated recent scientific advances (Tables 2 and 3 ). We should perhaps design programs such as the "Year(s) of the Egg" (YOTE) which would help to foster and organize among countries a large-scale initiative to monitor fecundity and egg size differences among stocks in the north Atlantic (perhaps under different food availability, condition factor or water temperature regimes - see for example the long-term study by Kjesbu et al. (1998) on Arcto-Norwegian cod). Careful concern during collection of wild specimens would have to be given to the level of gonad ripeness, as eggs expressed from ovaries that are unripe might be less viable and could evidently complicate comparisons of ova viability (Solemdal et al., MS 1992; Marteinsdottir and Steinarsson, 1998). Many of these concerns have been dealt with in Norwegian and Icelandic studies, and underline the complexity of gaining accurate estimates of an individual's annual viable egg production. These field values in association with controlled laboratory experiments (e.g. water temperature, ration level) using captive cod, haddock, pollock and flatfishes would be very useful in providing data to better represent the annual reproductive potential of a given stock. However, one should not lose sight of the additional costs associated with these evaluations.

Ideally, we should search for a rapid method of estimating stock reproductive potential via annual routine monitoring and this should be stock specific. Under present research budgets it is unrealistic to presume that annual fecundity estimates can be made for each stock over a long time series. Studies have shown that a parent's inherent energy supply (e.g. reflected by liver weight and/or condition factor) may help to predict actual fecundity (Kjesbu et al., 1991; Lambert and Dutil, 1997b; Krohn et al., 1997). These simple indicators of reproductive potential may correlate with fecundity or egg size and could be collected annually (e.g. Yaragina, MS 1996) and be used to estimate parameters within an SRP formulation. It would be wise to separate out which components would need to be sampled annually (e.g. age, maturation, condition, and liver weight) and which components (e.g. fecundity and size and viability of eggs) could be estimated from these routinely monitored variables.

Simple correlations have also been noted between gadoid recruitment and body size-at-age (Marshall and Frank, 1999) and an index of age diversity (Marteinsdottir and Thorarinsson, 1998). Further exploration of such stock-specific tools to predict recruitment should be encouraged. These 
TABLE 9. Fecundity estimates of northwest Atlantic cod based on wild specimens, 1878-present.

\begin{tabular}{|c|c|c|c|c|}
\hline Location & FL/WT & $\mathrm{N}$ & Year & Source \\
\hline Cape Ann, MA & $10-34 \mathrm{~kg}$ & 6 & $1878-79$ & Earll (1880) \\
\hline \multirow[t]{2}{*}{ Gulf of St. Lawrence, $4 \mathrm{~T}$} & $51-140 \mathrm{~cm}$ & 39 & $1955-56$ & Powles (1958) \\
\hline & $48-103 \mathrm{~cm}$ & 30 & 1980 & Buzeta and Waiwood (1982) \\
\hline $2 \mathrm{~J}, 3 \mathrm{~K}$ & & 28 & 1964 & May (1967) \\
\hline $3 \mathrm{~L}$ & & 21 & 1964 & \\
\hline $3 \mathrm{~N}$ & & 41 & $1964-65$ & \\
\hline 30 & & 40 & 1964 & \\
\hline All & $50-128 \mathrm{~cm}$ & & & \\
\hline \multirow[t]{2}{*}{ Bonavista Bay } & $65-109 \mathrm{~cm}$ & 19 & 1967 & Pinhorn (1984) \\
\hline & & 39 & 1968 & \\
\hline \multirow[t]{2}{*}{ Trinity Bay } & $60-108 \mathrm{~cm}$ & 28 & 1967 & \\
\hline & & 50 & 1968 & \\
\hline \multirow[t]{2}{*}{ St. John's } & $61-118 \mathrm{~cm}$ & 12 & 1966 & \\
\hline & & 50 & 1968 & \\
\hline Placentia Bay & $64-113 \mathrm{~cm}$ & 96 & 1966 & \\
\hline \multirow[t]{5}{*}{ St. Pierre Bank } & $51-138 \mathrm{~cm}$ & 13 & 1967 & \\
\hline & & 3 & 1968 & \\
\hline & & 43 & 1969 & \\
\hline & & 45 & 1970 & \\
\hline & Total & 603 & ividuals & \\
\hline
\end{tabular}

correlates of recruitment should be used to augment information on critical levels of stock reproductive status upon which managers may act to open or close a fishery.

\section{Summary}

This symposium is intended to present some of the recent findings on sexual maturation, condition and SSB variation in groundfish stocks. After a scientific hiatus for several decades in the area of parent-progeny relationships, a great deal has been accomplished over the past decade (Solemdal, 1997). This interest has been timely and mainly fueled by problems in the groundfish fisheries.

The task of understanding reproductive variation in batch-spawning fishes is challenging and poses very interesting questions to the scientists involved in this line of work. Had this basic research been conducted during the $1970 \mathrm{~s}-80 \mathrm{~s}$, when arguably a disproportionately large effort was being placed on quantitative aspects of assessments, fishery managers would perhaps have been better prepared, at least in eastern Canada, to set minimum SSB thresholds or other conservation thresholds to protect against recruitment overfishing.
An appropriate mix of scientific expertise is required with rapid integration where necessary. This includes support for routine monitoring of reproductive variables so that timely conservationminded advice can be made on the vulnerability of fish stocks to overexploitation. Further basic research into fish adult life histories is strongly recommended. A master plan is required to integrate these findings into resource management, perhaps in the form of a term such as SRP.

\section{Acknowledgements}

The author greatly appreciates the Steering Committee's invitation to present this paper at the NAFO Symposium on "Variations in Maturation, Growth, Condition and Spawning Stock Biomass Production in Groundfish" held in Lisbon, Portugal from 9-11 September 1998. The author also thanks those who provided comments on an earlier draft of the manuscript. Financial support was made available by DFO High Priority Funding.

\section{References}

AMIRO, P. G., R. E. CUTTING, J. H. INGRAM, and A. J. MCNEIL. MS 1985. Correlations between MSW salmon and 1SW grilse the previous year in 
the fisheries statistical districts, fishways and salmon management zones of the Scotia-Fundy region. CAFSAC Res. Doc., No. 110.

ANNAND, C., D. BEANLANDS, and J. MCMILLAN. MS 1990. Assessment of pollock (Pollachius virens) in Divisions 4VWX and Subdivision 5Zc for 1989. CAFSAC Res. Doc. No. 42.

BAIRD, J. W., and C. A. BISHOP. MS 1985. Assessment of the cod stock in NAFO Divisions $2 \mathrm{~J}+3 \mathrm{KL}$. NAFO SCR Doc. No. 37.

BAIRD, J. W., C. A. BISHOP, and R. WELLS. MS 1986. Estimates of age and length at maturity for cod in NAFO Divisions 2J+3KLNO. NAFO SCR Doc. No. 122.

BAIRD, J. W., C. A. BISHOP, and W. B. BRODIE. MS 1990. The assessment of the cod stock in NAFO Divisions 2J, 3K, and 3L. CAFSAC Res. Doc. No. 18.

BEACHAM, T. D. 1983. Variability in median size and age at sexual maturity of Atlantic cod (Gadus morhua) on the Scotian Shelf in the Northwest Atlantic Ocean. Fish. Bull., 81: 303-321.

BENHAM, A. A., and E. A. TRIPPEL. MS 1998. Mapping fishermen's knowledge of groundfish and herring spawning and nursery areas in the Bay of Fundy and Gulf of Maine. Report for the Gulf of Maine Council of the Marine Environment.

BEVERTON, R. J. H., and S. J. HOLT. 1957. On the dynamics of exploited fish populations. Fishery Invest. Lond., Ser. II, 19: 533 p.

BISHOP, C. A., D. E. STANSBURY and E. F. MURPHY. MS 1995a. An update of the stock status of Div. 2J3KL cod. DFO. Atl. Fish. Res. Doc. No. 34.

BISHOP, C. A., E. F. MURPHY, and D. E. STANSBURY. MS 1995b. Status of the cod stock in NAFO Subdivision 3Ps. DFO. Atl. Fish. Res. Doc. No. 31.

BROUSSEAU, C. S., and E. R. ARMSTRONG. 1987. The role of size limits in walleye management. Fisheries, 12: 2-5.

BUCKLEY, L. J., A. S. SMIGLESKI, T. A. HALAVIK, E. M. CALDARONE, B. R. BURNS, and G. C. LAURENCE. 1991. Winter flounder Pseudopleuronectes americanus reproductive success. II. Effects of spawning time and female size on size, composition and viability of eggs and larvae. Mar. Ecol. Progr. Ser., 74: 125-135.

BURTON, M. P. M., R. M. PENNEY and S. BIDDISCOMBE. 1997. Time course of gametogenesis in Northwest Atlantic cod (Gadus morhua). Can. J. Fish. Aquat. Sci., 54 (Suppl. 1): 122-131.

BUZETA, M.-I., and K. G. WAIWOOD. 1982. Fecundity of Atlantic cod (Gadus morhua) in the southwestern Gulf of St. Lawrence. Can. Tech. Rep. Fish. Aquat. Sci., 1110.

CADDY, J. F., and R. MAHON. 1995. Reference points for fisheries management. FAO Fisheries Technical Paper. No. 347. Rome, FAO.

CAMPANA, S., and J. HAMEL. MS 1990. Assessment of the $19894 \mathrm{X}$ cod fishery. CAFSAC Res. Doc.
No. 44.

CAMPANA, S., and J. SIMON. MS 1985. An analytical assessment of the $4 \mathrm{X}$ cod fishery. CAFSAC Res. Doc. No. 32.

CHAMBERS, R. C., and W. C. LEGGETT. 1996. Maternal influences on variation in egg sizes in temperate marine fishes. Amer. Zool., 36: 180-196.

CHAMBERS, R.C., and K. G. WAIWOOD. 1996. Maternal and seasonal differences in egg sizes and spawning characteristics of captive Atlantic cod, Gadus morhua. Can. J. Fish. Aquat. Sci., 53: 19862003.

CHOUINARD, G. A., and D. CLAY. MS 1985. Assessment of the $4 \mathrm{TVn}$ (Jan-Apr) cod stock for 1985. CAFSAC Res. Doc., No. 82.

CHOUINARD, G. A., G. A. NIELSEN, L. G. CURRIE, and J. P. MURPHY. MS 1990. Stock status of the southern Gulf of St. Lawrence cod stock (4T and 4Vn (Jan.-Apr.)) in 1990. CAFSAC Res. Doc., No. 46.

CLARK, D., E. A. TRIPPEL, and L. L. BROWN. MS 1995. Assessment of cod in Division 4X in 1994. DFO. Atl. Fish. Res. Doc., No. 28.

DE CIECHOMSKI, J. Dz. 1966. Development of the larvae and variations in the size of the eggs of the Argentine anchovy, Engraulis achoita Hubbs and Marini. ICES J. Cons., 30: 281-290.

DE MARTINI, E. E. 1991. Annual variations in fecundity, egg size, and the gonadal and somatic conditions of queenfish Seriphus politus (Sciaenidae). Fish. Bull. U.S., 89: 9-18.

DFO MS 1997a. Southern Scotian Shelf and Bay of Fundy cod. DFO Science Stock Status Report A3-05 (1997). Maritimes Regional Advisory Process, Department of Fisheries and Oceans, P. O. Box 1006, Dartmouth, Nova Scotia.

MS 1997b. Eastern Scotian shelf haddock. DFO Science Stock Status Report A3-06 (1997). Maritimes Regional Advisory Process, Department of Fisheries and Oceans, P. O. Box 1006, Dartmouth, Nova Scotia.

MS 1997c. Southern Scotian shelf and Bay of Fundy haddock. DFO Science Stock Status Report A3-07 (1997). Maritimes Regional Advisory Process, Department of Fisheries and Oceans, P. O. Box 1006, Dartmouth, Nova Scotia.

MS 1997d. Pollock in 4VWX5Zc. DFO Science Stock Status Report A3-13 (1997). Maritimes Regional Advisory Process, Department of Fisheries and Oceans. P. O. Box 1006, Dartmouth, Nova Scotia.

MS 1998a. Cod in the southern Gulf of St. Lawrence. DFO Science Stock Status Report A3-01 (1998). Maritimes Regional Advisory Process, Department of Fisheries and Oceans, P.O. Box 1006, Dartmouth, Nova Scotia.

MS 1998b. Cod in Sydney Bight. DFO Science Stock Status Report A3-02 (1998). Maritimes Regional Advisory Process, Department of Fisheries 
and Oceans. P. O. Box 1006, Dartmouth, Nova Scotia.

MS 1998c. Eastern Scotian Shelf cod. DFO Science Stock Status Report A3-03 (1998). Maritimes Regional Advisory Process, Department of Fisheries and Oceans. P. O. Box 1006, Dartmouth, Nova Scotia.

MS 1998d. Georges Bank cod in $5 \mathrm{Zj}, \mathrm{m}$. DFO Science Stock Status Report A3-04 (1998). Maritimes Regional Advisory Process, Department of Fisheries and Oceans. P. O. Box 1006, Dartmouth, Nova Scotia.

MS 1998e. Eastern Georges Bank haddock. DFO Science Stock Status Report A3-08 (1998), Maritimes Regional Advisory Process, Department of Fisheries and Oceans. P. O. Box 1006, Dartmouth, Nova Scotia.

EARLL, R. E. 1880. A report on the history and the present condition of the shore cod-fisheries of Cape Ann, Massachusetts together with notes on the natural and artificial propagation of the species. Rep. U.S. Fish. Comm. for 1878(6): 685-740.

ELLERTSEN, B., and P. SOLEMDAL. MS 1990. Spawning strategy and a mechanism for adaptive larval production in Arcto-Norwegian cod. ICES C.M. Doc., No. LL 100, 15 p.

FANNING, L. P., and W. J. MACEACHERN. MS 1990. Stock status of $4 \mathrm{VsW}$ cod in 1989 using a half-year SPA formulation. CAFSAC Res. Doc., No. 88.

FANNING, L. P., R. K. MOHN, and W. J. MACEACHERN. MS 1995. Assessment of 4VsW cod in 1994 with consideration of ecological indicators on stock status. DFO. Atl. Fish. Res. Doc., No. 73.

FAO. MS 1995. Precautionary approaches to fisheries. Part 1: Guidelines on the precautionary approach to capture fisheries and species introductions. FAO Fisheries Technical Paper, No. 350, Part 1. Rome, FAO 52.

FORDHAM, S. E., and E. A. TRIPPEL. 1999. Feeding behaviour of cod (Gadus morhua) in relation to spawning. J. Appl. Ichthyol., 15: 1-9.

FRANK, K. T., P. C. F. HURLEY, and J. SIMON. MS 1990. Assessment of $4 \mathrm{X}$ haddock in 1989. CAFSAC Res. Doc., No. 58.

FRCC. MS 1997. A groundfish conservation framework for Atlantic Canada (July, 1997). Report FRCC.97.R.3, Fisheries Resource Conservation Council, P.O. Box 2001, Ottawa.

FRÉCHET, A., and P. SCHWAB. MS 1990. La pêche de la morue dans le nord-ouest du Golfe du St. Laurant en 1989 (3Pn,4Rs), l'analse des prises, de l'effort de pêche et l'estimation de la biomasse. CAFSAC Res. Doc., No. 60.

MS 1995. Review of the status of the northern Gulf of St. Lawrence cod stock (3Pn,4RS) in 1994. DFO. Atl. Fish. Res. Doc., No. 53.

GASCON, D., and A. FRÉCHET. MS 1985. An assessment of the cod stock in NAFO Divisions $4 \mathrm{R}$
4S and in Subdivision 3Pn. CAFSAC Res. Doc., No. 107.

GAVARIS, S., and L. VAN EECKHAUTE. MS 1990. Assessment of haddock on eastern Georges Bank. CAFSAC Res. Doc., No. 86.

MS 1995. Assessment of haddock on eastern Georges Bank. DFO. Atl. Fish. Res. Doc., No. 6.

GOODYEAR, C. P. 1993. Spawning stock biomass per recruit in fisheries management: foundation and current use. In: Risk evaluation and biological reference points for fisheries management. S.J. Smith, J.J. Hunt, and D. Rivard (eds.). Can. Spec. Publ. Fish. Aquat. Sci., 120: 67-82.

GRAUMAN, G. B. MS 1964. The importance of the size of the eggs of the Baltic cod for survival of foetuses. ICES C.M. Doc., No. F:85.

HEINCKE, F., and E. EHRENBAUM. 1900. Eier und Larven von Fischen der deutschen Bucht, II. Bestimmung der schwimmenden Fischeier und die Methodik der Eimessungen. Wiss. Meeresunters. Helgol., 3: 127-333.

HEMPEL, G. and J. H. S. BLAXTER. 1967. Egg weight in Atlantic herring (Clupea harengus, L.). ICES $J$. Cons., 31: 170-195.

HISLOP, J. R. G. 1988. The influence of maternal length and age on the size and weight of the eggs and the relative fecundity of haddock, Melanogrammus aeglefinus, in British waters. J. Fish Biol., 32: 923-930.

HUNT, J. J. MS 1990. Status of the Atlantic cod stock on Georges Bank in unit areas $5 \mathrm{Zj}$ and $5 \mathrm{Zm}, 1978-$ 89. CAFSAC Res. Doc., No. 80.

1996. Rates of sexual maturation of Atlantic cod in NAFO Division 5Ze and commercial fishery implications. J. Northw. Atl. Fish. Sci., 18: 61-75.

HUNT, J. J., and M.-I. BUZETA. MS 1995. Biological update of Georges Bank cod in unit areas $5 \mathrm{Zj}, \mathrm{m}$ for 1978-94. DFO. Atl. Fish. Res. Doc., No. 5.

HUNT, J. J., and K.G. WAIWOOD. MS 1985. Status of the Atlantic cod stock on Georges Bank, NAFO Division 5Z and Statistical Area 6, 1984. CAFSAC Res. Doc., No. 87.

HURLEY, P. C. F., G. A. P. BLACK, R. MOHN, and P. COMEAU. MS 1995. Assessment of 4X haddock in 1994. DFO. Atl. Fish. Res. Doc., No. 29.

HUTCHINGS, J. A., and R. A. MYERS. 1993. The effect of age on the seasonality of maturation and spawning of Atlantic cod, Gadus morhua. Can. J. Fish. Aquat. Sci., 50: 2468-2474.

1994. What can be learned from the collapse of a renewable resource? Atlantic cod, Gadus morhua, of Newfoundland and Labrador. Can. J. Fish. Aquat. Sci., 51: 2126-2146.

ICES MS 1997. Report of the Study Group on the precautionary approach to fisheries management. ICES C.M. 1997 Doc., No. Assess:7. 37 p.

JENSEN, A. L. 1981. Optimum size limits for trout fisheries. Can. J. Fish. Aquat. Sci., 38: 657-661.

KJESBU, O. S. 1989. The spawning activity of cod, 
Gadus morhua L. J. Fish Biol., 34: 195-206.

KJESBU, O. S., J. KLUNGS ØYR, H. KRYVI, P. R. WITTHAMES, and M. GREER WALKER. 1991. Fecundity, atresia, and egg size of captive Atlantic cod (Gadus morhua) in relation to proximate body composition. Can. J. Fish. Aquat. Sci., 48: 23332343.

KJESBU, O. S., P. SOLEMDAL, P. BRATLAND, and M. FONN. 1996. Variation in annual egg production in individual captive Atlantic cod (Gadus morhua). Can. J. Fish. Aquat. Sci., 53: 610-620.

KJESBU, O. S., P. R. WITTHAMES, P. SOLEMDAL, and M. GREER WALKER. 1998. Temporal variations in the fecundity of Arcto-Norwegian cod (Gadus morhua) in response to natural changes in food and temperature. J. Sea Res., 40: 303-321.

KOSLOW, J.A. 1992. Fecundity and the stockrecruitment relationship. Can. J. Fish. Aquat. Sci., 49: 210-217.

KROHN, M., S. REIDY, and S. KERR. 1997. Bioenergetic analysis of the effects of temperature and prey availability on growth and condition of northern cod (Gadus morhua). Can. J. Fish. Aquat. Sci., 54(Suppl. 1): 113-121.

LAMBERT, T. C., and S. J. SMITH. MS 1990. 4Vn cod (May to December): Status review for the 1989 fishing year. CAFSAC Res. Doc., No. 47.

LAMBERT, T. C., and S. WILSON. MS 1995. Update of the status of $4 \mathrm{Vn}$ cod: 1994. DFO. Atl. Fish. Res. Doc., No. 27.

LAMBERT, Y., and J.-D. DUTIL. 1997a. Condition and energy reserves of Atlantic cod (Gadus morhua) during the collapse of the northern Gulf of St. Lawrence stock. Can. J. Fish. Aquat. Sci., 54: 23882400 .

1997b. Can simple condition indices be used to monitor and quantify seasonal changes in the energy reserves of Atlantic cod (Gadus morhua)? Can. J. Fish. Aquat. Sci., 54(Suppl. 1): 104-112.

1999. Energetic consequences of reproduction in Atlantic cod (Gadus morhua) in relation to spawning level of somatic energy reserves. Can. J. Fish. Aquat. Sci., (in press).

LILLY, G.R. MS 1997. Size and condition of cod in Divisions 2J+3KL during 1978-1996. NAFO SCR Doc., No. 62.

Lilly, G. R., P. A. SHELTON, J. BRATTEY, N. CADIGAN, E. F. MURPHY, D. E. STANSBURY, M. B. DAVIS, D. W. KULKA, and M. J. MORGAN. MS 1998. An assessment of the cod stock in NAFO Divisions 2J+3KL. Can. Stock Assess. Sec. Res. Doc., No. 14.

LITVAK, M. K., and E. A. TRIPPEL. 1998. Sperm motility patterns of Atlantic cod (Gadus morhua) in relation to salinity: effects of ovarian fluid and egg presence. Can. J. Fish. Aquat. Sci., 55: 1871-1877.

MACE, P. M. and M. P. SISSENWINE. 1993. How much spawning per recruit is enough? In: Risk evaluation and biological reference points for fisheries management. S. J. Smith, J. J. Hunt, and D. Rivard (eds.), Can. Spec. Publ. Fish. Aquat. Sci., 120: 101118.

MCGLADE, J., M. C. ANNAND, and D. BEANLANDS. MS 1985. The exploitation and biological status of pollock in divisions $4 \mathrm{VWX}$ and Subarea 5. CAFSAC Res. Doc., No. 99.

MACKENZIE, B. R., J. TOMKIEWICZ, F. KÖSTER, and A. NISSLING. MS 1998. Quantifying and disaggregating the spawner effect: Incorporating stock structure, spatial distribution and female influences into estimates of annual population egg production. ICES C.M. Doc., No. BB 11 Theme Session on Fisheries Assessment Methods.

MAGUIRE, J.-J., and P. M. MACE. 1993. Biological reference points for Canadian Atlantic gadoid stocks. In: Risk evaluation and biological reference points for fisheries management. S. J. Smith, J. J. Hunt, and D. Rivard (eds.). Can. Spec. Publ. Fish. Aquat. Sci., 120: 321-332.

MAHON, R., P. SIMPSON, and D. E. WALDRON. MS 1985. The eastern Scotian shelf (4VW) haddock stock and fishery in 1984, with an historical perspective on stock and recruitment back to 1948 . CAFSAC Res. Doc., No. 47.

MARSHALL, C. T., and K. T. FRANK. 1999. The effect of interannual variation in growth and condition of haddock (Melanogrammus aeglefinus) on recruitment. Can. J. Fish. Aquat. Sci., 56: 347-355.

MARSHALL, C. T., O. S. KJESBU, N. A. YARAGINA, P. SOLEMDAL and $\varnothing$. ULLTANG. 1998. Is spawner biomass a sensitive measure of the reproductive and recruitment potential of Northeast Arctic cod? Can. J. Fish. Aquat. Sci., 55: 1766-1783.

MARTEINSDOTTIR, G., and A. STEINARSSON. 1998. Maternal influence on the size and viability of Iceland cod Gadus morhua eggs and larvae. J. Fish Biol., 52: 1241-1258.

MARTEINSDOTTIR, G., and K. THORARINSSON. 1998. Improving the stock-recruitment relationship in Icelandic cod (Gadus morhua L.) by including age diversity of spawners. Can. J. Fish. Aquat. Sci., 55: 1372-1377.

MAY, A.W. 1967. Fecundity of Atlantic cod. J. Fish. Res. Board Can. 24: 1531-1551.

MCEVOY, L. A., and J. MCEVOY. 1991. Size fluctuation in the eggs and newly hatched larvae of captive turbot (Scopthalmus maximus). J. Mar. Biol. Assoc. U.K., 71: 679-690.

MORGAN, M. J., and E. A. TRIPPEL. 1996. Skewed sex ratios in spawning shoals of Atlantic cod (Gadus morhua). ICES J. Mar. Sci., 53: 820-826.

MURAWSKI, S. A., P. J. RAGO, and E. A. TRIPPEL. 1999. Impacts of demographic variation in spawning success on reference points for fishery management. Proceedings, $5^{\text {th }}$ NMFS NSAW, NOAA Tech. Memo., NMFS-F/SPO-40, p. 77-83.

MYERS, R. A., G. MERTZ, and S. FOWLOW. 1997. The maximum population growth rates and recovery times 
of Atlantic cod (Gadus morhua). Fish. Bull. U.S., 95: 762-772.

MYERS, R. A., A. A. ROSENBERG, P. M. MACE, N. BARROWMAN, and V. R. RESTREPO. 1994. In search of thresholds for recruitment overfishing. ICES J. Mar. Sci., 51: 191-205.

NEILSON, J. D., and P. PERLEY. MS 1995. The 1994 assessment of pollock (Pollachius virens) in NAFO Divisions 4VWX and Subdivision 5Zc. DFO. Atl. Fish. Res. Doc., No. 30.

NISSLING, A., R. LARSSON, L. VALLIN, and K. FROHLUND. 1998. Assessment of egg and larval viability in cod, Gadus morhua: methods and results from an experimental study. Fish. Res., 38: 169-186.

NISSLING, A., and L. WESTIN. 1991. Egg mortality and hatching rate of Baltic cod (Gadus morhua) in different salinities. Mar. Biol., 111: 29-32.

NOVINGER, G. D. 1990. Slot length limits for largemouth bass in small private impoundments. $N$. Amer. J. Fish. Manag., 10: 330-337.

O'BOYLE, R., and R. GREGORY. MS 1985. An evaluation of the population dynamics of $4 \mathrm{X}$ haddock during 1962-84 with yield projected to 1986 . CAFSAC Res. Doc., No. 109.

O'CONNEL, M.F. and D.G. REDDIN. MS 1983. Egg depositions in some Newfoundland rivers. CAFSAC Res. Doc., No. 15.

O'CONNEL, M.F. MS 1986. Atlantic salmon (Salmo salar L.) egg deposition potential and annual smolt production for three river systems characterized by lacustrine habitat in insular Newfoundland. CAFSAC Res. Doc., No. 85.

O'CONNEL, M.F., and J.B. DEMPSON. MS 1991. Atlantic salmon (Salmo salar L.) target spawning requirements for rivers in Notre Dame Bay (SFA 4), St. Mary's Bay (SFA 9), and Placentia Bay (SFA 10), Newfoundland. CAFSAC Res. Doc., No. 17.

PAULIK, G.J. 1973. Studies of the possible form of the stock-recruitment curve. ICES Rapp. Proc-Verb., 164: 302-315.

PINHORN, A.T. 1984. Temporal and spatial variation in fecundity of Atlantic cod (Gadus morhua) in Newfoundland waters. J. Northw. Atl. Fish. Sci., 5: 161-170.

POWLES, P.M. 1958. Studies of reproduction and feeding of Atlantic cod (Gadus callarias L.) in the southwestern Gulf of St. Lawrence. J. Fish. Res. Board Can., 15: 1383-1402.

RAKITIN, A., M. M. FERGUSON, and E. A. TRIPPEL. 1999a. Spermatocrit and spermatozoa density in Atlantic cod (Gadus morhua): correlation and variation during the spawning season. Aquaculture 170: $349-358$.

1999b. Sperm competition and fertilization success in Atlantic cod (Gadus morhua): effect of sire size and condition factor on gamete quality. Can. J. Fish. Aquat. Sci., (in press).

RICE, J., and G. EVANS. MS 1986. Re-examining target spawning biomass for the cod stock in NAFO
Divisions 2J+3KL. NAFO SCR No. 30.

RICKER, W. E. 1954. Stock and recruitment. J. Fish. Res. Board Can., 11: 559-623.

RITTER, J. A., T. L. MARSHALL, and P. R. BOUDREAU. MS 1990. Model development for predicting multi-sea-winter Atlantic salmon (Salmo salar L.) returns to Saint John River, New Brunswick. CAFSAC Res. Doc., No. 84.

ROGERS, B. A., and D. T. WESTIN. 1981. Laboratory studies on effects of temperature and delayed initial feeding on development of striped bass larvae. Trans. Amer. Fish. Soc., 110: 100-110.

ROTHSCHILD, B.J., and M.J. FOGARTY. 1989. Spawning stock biomass: a source of error in recruitment/stock relationships and management advice. ICES J. Cons., 45: 131-135.

SCARNECCHIA, D.L., T.W. GENGERKE, and C.T. MOEN. 1989. Rational for a harvest slot limit for paddlefish in the upper Mississippi River. N. Amer. J. Fish. Manag., 9: 477-487.

SERCHUK, F., D. RIVARD, J. CASEY, and R. MAYO. MS 1997. Report of the ad hoc working group of the NAFO Scientific Council on the precautionary approach. NAFO SCS Doc., No 12, Serial No. 2911, $61 \mathrm{p}$.

SEREBRYAKOV, V. P. 1991. Prediction of year-class strength under uncertainties related to survival in early life history of some north Atlantic commercial fish. NAFO Sci. Coun. Studies, 16: 49-56.

SHEPHERD, J. G. 1982. A versatile new stockrecruitment relationship for fisheries, and the construction of sustainable yield curves. ICES J. Cons., 40: 67-75.

SINCLAIR, A., G. CHOUINARD, D. SWAIN, G. NIELSEN, M. HANSON, L. CURRIE, T. HURLBUT, and R. HÉBERT. MS 1995. Assessment of the southern Gulf of St. Lawrence cod stock, March 1995. DFO. Atl. Fish. Res. Doc., No. 39.

SINCLAIR, A., and S. GAVARIS. MS 1985. Sequential population analysis of $4 \mathrm{VsW}$ cod following the 1984 fishery. CAFSAC Res. Doc., No. 48.

SISSENWINE, M. P., and J. G. SHEPHERD. 1987. An alternative perspective on recruitment overfishing and biological reference points. Can. J. Fish. Aquat. Sci., 44: 913-918.

SMITH, S. J., and A. F. SINCLAIR. MS 1985. 4Vn cod (May-December): Status review for the 1984 fishing year. CAFSAC Res. Doc., No. 63.

SOLEMDAL, P. MS 1970. Intraspecific variations in size, buoyancy and growth of eggs and early larvae of Arcto-Norwegian cod, Gadus morhua L., due to parental and environmental effects. ICES C.M. Doc., No. F:28.

1997. Maternal effects - a link between the past and the future. J. Sea Res., 37: 213-227.

SOLEMDAL, P., Ø. BERGH, R. N. FINN, H. J. FYHN, O. GRAHL-NIELSEN, O. HOMME, O. S. KJESBU, E. KJØRSVIK, I. OPSTAD, and A. B. SKIFTESVIK. MS 1992. The effects of maternal status of Arcto- 
Norwegian cod on egg quality and vitality of early larvae. II. Preliminary results of the experiment in 1992. ICES C. M. Doc., No. G:79.

SOLEMDAL, P., KJESBU, O. S., and M. FONN. MS 1995. Egg mortality in recruit- and repeat-spawning cod - an experimental study. ICES C.M. Doc., G:35.

STANSBURY, D. E., P. A. SHELTON, J. BRATTEY, G. R. LILLY, G. WINTERS, E. F. MURPHY, M. B. DAVIS, and D. W. KULKA. MS 1998. An assessment of the cod stock in NAFO Subdivision 3Ps. DFO. Atl. Fish. Res. Doc., No. 19.

SUND, O., G., ROLLEFSEN, and J. EGGVIN. 1938. Torsken og fiskehavet 1937. Fiskeridir. Skr. Ser. Havunders., 5: 1-52.

TRIPPEL, E.A. 1993. Relations of fecundity, maturation and body size of lake trout, and implications for management in northwestern Ontario lakes. N. Amer. J. Fish. Manag., 13: 64-72.

1995. Age at maturity as a stress indicator in fisheries. BioScience, 45: 759-771.

1998. Egg size and viability and seasonal offspring production of young Atlantic cod. Trans. Amer. Fish. Soc., 127: 339-359.

TRIPPEL, E. A., M.-I. BUZETA, and J. J. HUNT. 1995. Evaluation of the cost of reproduction in Georges Bank Atlantic cod (Gadus morhua): utility of otolith backcalculation. In: Recent developments in fish otolith research. D. H. Secor, J. M. Dean, and S. E. Campana (eds.). University of South Carolina Press, Columbia, SC., p. 599-616.

TRIPPEL, E. A., O. S. KJESBU, and P. SOLEMDAL. 1997b. Effects of adult age and size structure on reproductive output in marine fishes. In: Early life history and recruitment in fish populations. R. C. Chambers and E. A. Trippel (eds.). Chapman and Hall, New York, p. 31-62.

TRIPPEL, E. A., and M. J. MORGAN. 1994a. Agespecific paternal influences on reproductive success in Atlantic cod (Gadus morhua) of the Grand Banks,
Newfoundland. ICES Mar. Sci. Symp., 198: 414-422. 1994b. Sperm longevity in Atlantic cod (Gadus morhua). Copeia, 1994: 1025-1029.

TRIPPEL, E. A., M. J. MORGAN, A. FRÉCHET, C. ROLLET, A. SINCLAIR, C. ANNAND, D. BEANLANDS, and L. BROWN. 1997a. Changes in age and length at sexual maturity of Northwest Atlantic cod, haddock and pollock stocks, 1972-1995. Can. Tech. Rep. Fish. Aquat. Sci., 2157, 120 p.

TRIPPEL, E. A., and J. D. NEILSON. 1992. Fertility and sperm quality of virgin and repeat-spawning Atlantic cod (Gadus morhua) and associated hatching success. Can. J. Fish. Aquat. Sci., 49: 2118-2127.

ULLTANG, Ø. 1996. Stock assessment and biological uncertainty: can prediction uncertainty be reduced? ICES J. Mar. Sci., 53: 659-675.

WAIWOOD, K.G., and J. D. NEILSON. MS 1985. The 1985 assessment of 5Ze haddock. CAFSAC Res. Doc., No. 95.

WALTERS, C., and J. J. MAGUIRE. 1996. Lessons for stock assessment from the northern cod collapse. Rev. Fish Biol. Fish., 6: 125-137.

WILSON-SHORT, C. E., L. W. CRIM, and M. J. MORGAN. 1995. The effects of stress on spawning performance and larval development in the Atlantic cod, Gadus morhua L. In: Proceedings of the Fifth International Symposium on the Reproductive Physiology of Fish. F. W. Goetz, and P. Thomas (eds.). The University of Texas at Austin, 2-8 July 1995, Fish Symposium 95, Austin, Texas (USA), 1995, p. 198.

YARAGINA, N. A. MS 1996. Change of liver condition index of North-east Arctic cod in the 1970-90s. ICES C.M. Doc. No. G:41.

ZWANENBURG, K. MS 1990. Haddock on the eastern Scotian shelf 1990. CAFSAC Res. Doc. No. 92.

ZWANENBURG, K., G.A.P. BLACK, and G. YOUNG. MS 1995. Haddock in Division 4TVW in 1994. DFO Atl. Fish. Res. Doc., No. 112. 
TRIPPEL: Stock Reproductive Potential

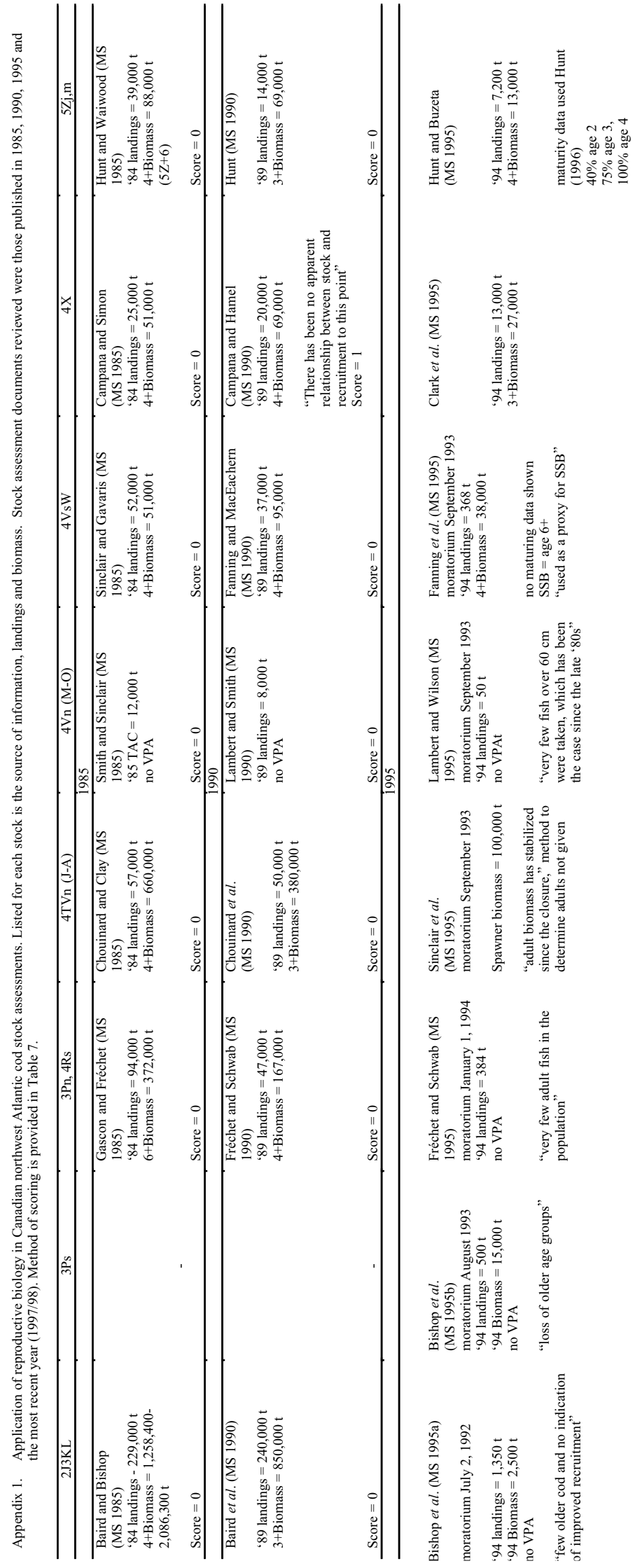




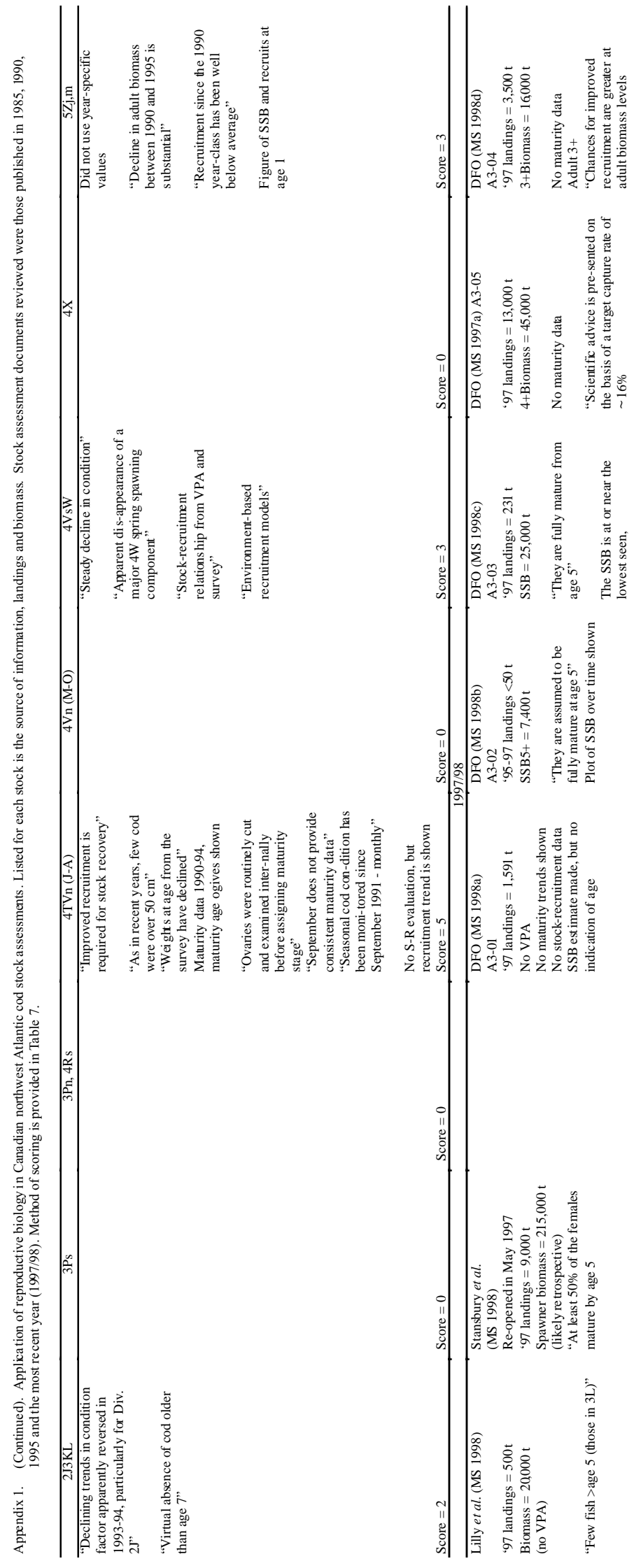




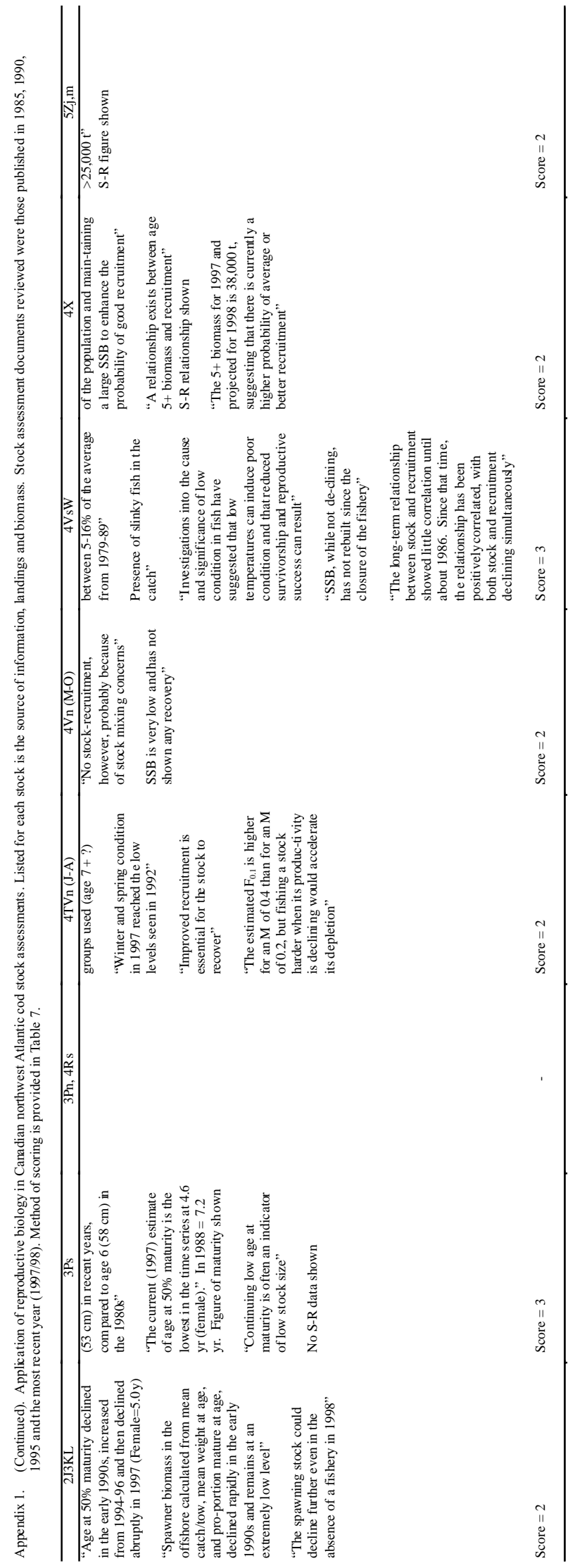




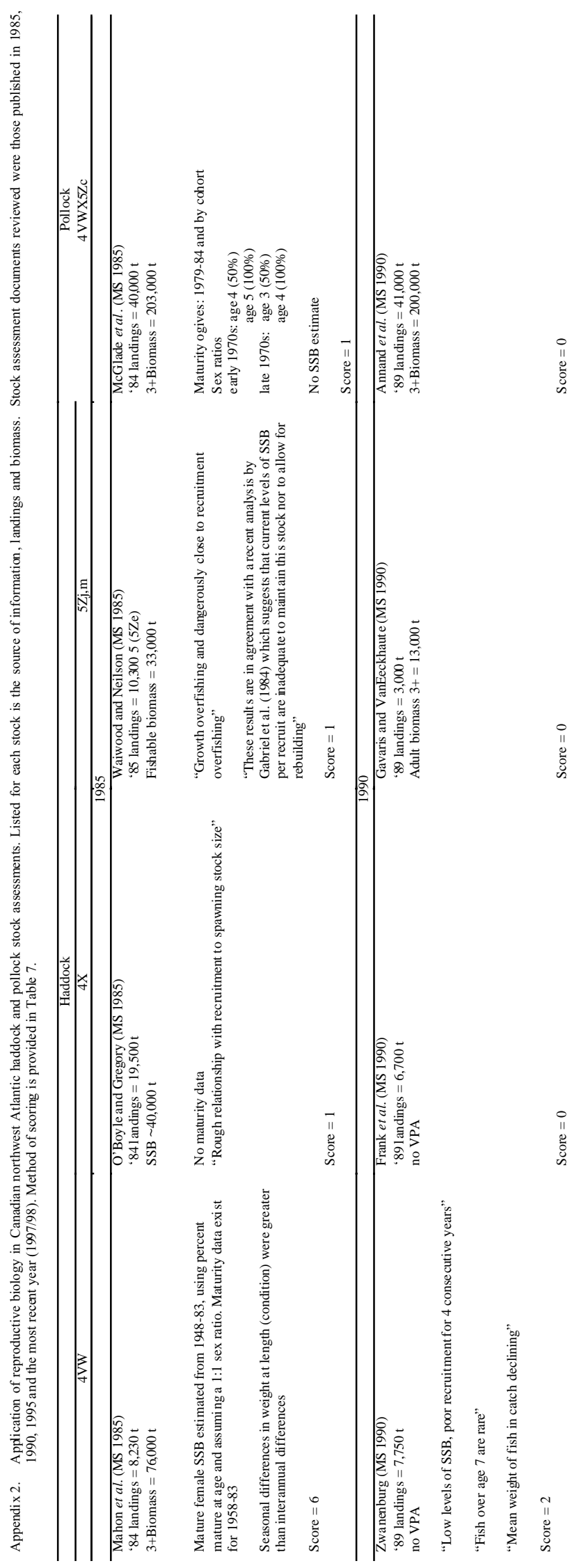


TRIPPEL: Stock Reproductive Potential

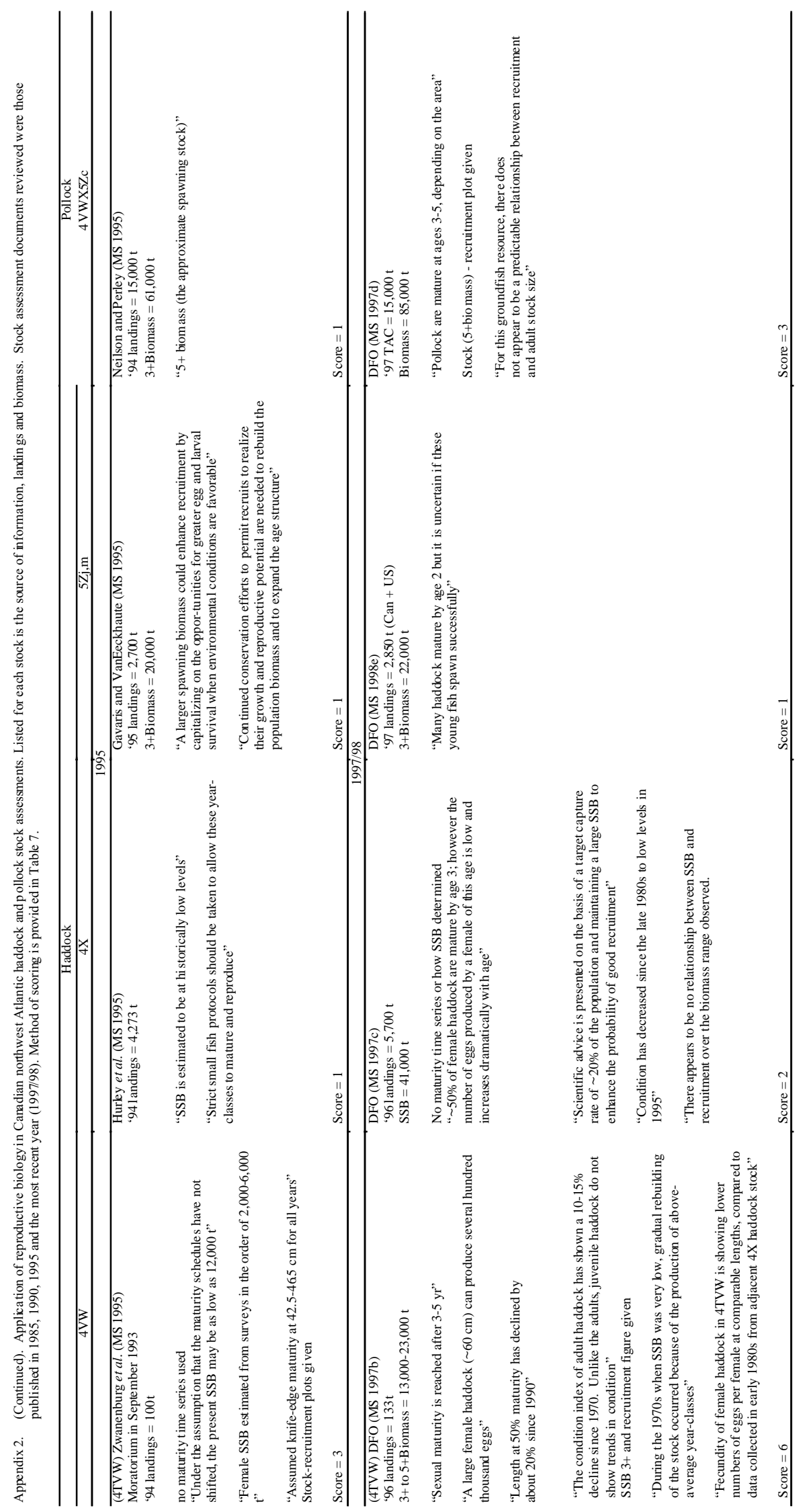


